\title{
A Rapid and Inexpensive Enzymatic Assay for Total Cyanide in Cassava (Manihot esculenta Crantz) and Cassava Products
}

\author{
C. O. Ikediobi,* G. O. C. Onyia and C. E. Eluwah \\ Department of Biochemistry, National Root Crops Research Institute (NRCRI) \\ P.M.B. 1006, Umuahia, Nigeria
}

Received March 25, 1980

\begin{abstract}
The well-known alkaline picrate test for cyanide has been improved by incorporating an enzymatic step to make the assay much more specific and quantitative. The sensitivity or detection limit of this method was found to be $0.16 \mu \mathrm{g} / \mathrm{cm}^{3}$ while the precision as indicated by the coefficient of variation was $3 \%$. The method was, in addition, found to be rapid, simple, inexpensive and ideally suited for the analysis of large number of cassava tissues and products, such as may be encountered in cassava agronomy and breeding work or in industrial quality control laboratories. A trained operator working alone consistently analyzed at least 700 samples/day using this assay method.
\end{abstract}

Cassava (Manihot esculenta Crantz) is an important dietary staple and a cheap source of calories for some $200 \sim 300$ million people in the tropical developing world. Its growing use for human food and animal feed, however, could be hampered by the presence of toxic cyanogens in its tubers. Acute cyanide toxicity in humans usually terminates in the death of the victim while chronic toxicity has been associated with goiter ${ }^{1,2)}$ and tropical ataxic neuropathy. ${ }^{3}$ ) The measurement of cyanide levels is of great importance to the plant breeder interested in breeding low cyanide cassava cultivars, the food technologist anxious to develop processing methods that would yield edible zero cyanide cassava products, and the toxicologist who may need to assess the extent of toxicity by monitoring blood levels of free cyanide and its biotransformation products.

Cyanide in intact cassava tuber exists largely as the aliphatic glucosides, linamarin and lotaustralin, but only the free cyanide is amenable to direct assay. The greatest problem in obtaining reliable and reproducible data, lies with the difficulty in achieving quantitative autolysis of the cyanogens in cassava extracts and quantitative recovery of the released

* Current address: Department of Biochemistry, Ahmadu Bello University, Zaria, Nigeria.
HCN." Most existing methods for cyanide assay are inadequate partly because of their inherent inability to eliminate this difficulty. ${ }^{51}$ In extracts from fresh cassava tubers, autolysis is aided tremendously by the action of endogenous linamarase (EC. 3.2.1.21; linamarin $\beta$ D-glucoside glucohydrolase) on the cyanogenic glucosides to release free $\mathrm{HCN}$. However, in extracts from processed cassava products, this is not possible since all enzymatic activity of the cassava parenchymatous tissue has been destroyed during processing. Therefore quantitative hydrolysis can only be assured by the use of exogenous linamarase of known activity.

Despite this obvious realisation, the unavailability of commercial linamarase and the dearth of literature information on its purification have for many years hindered the use of an enzymatic approach in cyanide analysis until very recently when Cooke et al. ${ }^{6)}$ published the purification of cassava linamarase and introduced the use of this enzyme in estimating total cyanide in cassava tubers and leaves. ${ }^{7,8)}$ Though a tremendously vast improvement over existing methods, Cooke's method has several problems. Firstly, the principal chemicals are rare and expensive. Secondly, the obligatory use of the unpleasantsmelling pyridine both as solvent and reactant, necessitates the installation of a fume chamber 
in any laboratory handling a large volume of cyanide analysis by this method. Thirdly, unpublished attempts to use this method by us and other workers ${ }^{9}$ have revealed other problems related to data reproducibility, reagent stability and the potentially toxic nature of the principal chemicals in use.

The present paper describes a rapid method which combines the specificity, sensitivity and quantitativeness of an enzyme-based assay with the simplicity and inexpensiveness of the popular alkaline picrate test. ${ }^{10 \sim 16)}$

\section{MATERIALS AND METHODS}

Materials. Fresh cassava tubers of known variety and age were harvested from the Institute's farms. Samples of the popular cassava product, gari, were obtained from various sources as indicated in Table $\mathrm{I}$.

Table I. Cyanide Content of Gari from Different SOURCES ${ }^{a}$

\begin{tabular}{|c|c|c|}
\hline & Source & $\begin{array}{c}\text { Cyanide } \\
\text { content (ppm) }\end{array}$ \\
\hline 1 & $\begin{array}{l}\text { National Root Crops Production } \\
\text { Company, Enugu }\end{array}$ & 52 \\
\hline 2 & $\begin{array}{l}\text { Federal Institute of Industrial } \\
\text { Research, Lagos }\end{array}$ & 54 \\
\hline 3 & $\begin{array}{l}\text { National Root Crops Research } \\
\text { Institute, Umuahia }\end{array}$ & 45 \\
\hline 4 & $\begin{array}{l}\text { Texaco Agro-Industrial (Nig.) Ltd., } \\
\text { Abeokuta }\end{array}$ & 36 \\
\hline 5 & Market in Otobi, Benue State & 47 \\
\hline 6 & Market in Ilorin, Kwara State & 13 \\
\hline 7 & $\begin{array}{l}\text { Imo State Agric. Development } \\
\text { Corporation, Ubani }\end{array}$ & 62 \\
\hline 8 & $\begin{array}{l}\text { Imo State Agric. Development } \\
\text { Corporation, Umukune }\end{array}$ & 57 \\
\hline
\end{tabular}

$9^{b}$ Fresh bitter cassava tuber $(60506) \quad 704.6$

$a$ Of the eight gari samples analysed, six (samples $1 \sim 4$ and $7 \sim 8$ ) were obtained already prepackaged in securely sealed polyethylene bags as dry, granular, free-flowing powder and had moisture content of $8 \sim 9 \%$. Samples 5 and 6 , although dry and granular, were purchased from the open market where they were being sold unpackaged in wide, open basins and had slightly higher moisture content of 11.2 and $12.4 \%$, respectively. Sample 9 which is fresh cassava tuber was not dried before cyanide determination and freshly harvested cassava is about $62 \sim 66 \%$ water. The cyanide concentration was expressed in parts per million (ppm) i.e., $\mathrm{mg} \mathrm{CN^{- }} / \mathrm{kg}$ dry gari.

b Included for sake of comparison.
Partially purified cassava linamarase was prepared in our Laboratory. Anhydrous picric acid was purchased from May and Baker, England. $p$-Nitrophenyl- $\beta$-Dglucoside (PNP-glucoside) was gratefully obtained from Dr. G. Umezurike of the Department of Biochemistry, University of Nigeria, Nsukka. Other routine chemicals and solvents used were of analytical grade.

Preparation of linamarase. The thin brown outer skin of freshly harvested cassava tubers was carefully removed revealing the underlying cortex. The latter was removed and sliced into small pieces. Approximately $100 \mathrm{~g}$ of the slices were homogenized in $300 \mathrm{ml}$ of prechilled $0.1 \mathrm{M}$ acetate buffer of $\mathrm{pH} 5.50$. The homogenate was collected in a prechilled container and filtered by suction through a $1 \mathrm{~cm}$-layer of kieselguhr. The filtrate was used to extract a second $100 \mathrm{~g}$ batch of sliced cassava cortex as described above. The filtrate from the second extraction was similarly used to extract a third $100 \mathrm{~g}$ batch. This final extract was kept overnight at $4^{\circ} \mathrm{C}$.

To this extract were added 2.3 volumes of cold acetone and the resulting solution swirled several times for $2 \mathrm{~min}$ within a 2 hr period. A pale-green precipitate was recovered upon decantation. This precipitate was subsequently extracted thrice with $10 \mathrm{ml}$ portions of cold $0.1 \mathrm{M}$ acetate buffer of $\mathrm{pH} 5.50$. The extract was centrifuged at $500 \times g$ for $5 \mathrm{~min}$ at room temperature and the resulting supernatant was dialyzed either at room temperature or in the cold room against $0.1 \mathrm{M}$ acetate buffer of $\mathrm{pH} 5.50$ to remove any residual linamarin. The extract obtained after dialysis was assayed for activity and subsequently used for cyanide assays.

Assay of linamarase activity. Both the crude preparation of, and the partially purified, cassava cortex linamarase were assayed for activity using $p$-nitrophenyl$\beta$-D-glucoside as the substrate.

One milliliter of a solution containing $62 \mathrm{mg}$ of PNP-glucoside in $0.01 \mathrm{M}$ sodium phosphate buffer of $\mathrm{pH} 6.8$ was incubated for one hour at room temperature $\left(25 \pm 2^{\circ} \mathrm{C}\right)$ with $0.5 \mathrm{ml}$ of the enzyme preparation. At the end of the incubation, the reaction was stopped by the addition of $2 \mathrm{ml}$ of $0.2 \mathrm{M}$ borate buffer of $\mathrm{pH} 9.80$. The reaction solution was then brought up to $4 \mathrm{ml}$ with distilled water and the absorbance of the resulting solution read at $400 \mathrm{~nm}$ in a Beckman Model 25 Spectrophotometer. One unit of linamarase activity was defined as that amount of enzyme which produced 0.001 change in absorbance at $400 \mathrm{~nm} / \mathrm{min}$ under the described assay conditions.

Preparation of cassava and cassava product extracts for cyanide analysis. About $20 \mathrm{~g}$ of fresh cassava parenchyma tissue were homogenized in $50 \mathrm{ml}$ of $0.1 \mathrm{M}$ $\mathrm{HCl}$ for $3 \mathrm{~min}$. The homogenate was filtered by vacuum 
and the resulting filtrate adjusted to $\mathrm{pH} 6.8$ with base. This solution was then centrifuged at $500 \times g$ for $3 \mathrm{~min}$. The resulting supernatant was then stored in the freezer until analysed.

Preparations from various processed cassava products were made in the same way as from the cassava tuber except that $150 \mathrm{ml}$ of $0.1 \mathrm{M}$ sodium phosphate buffer pH 6.8 was used in the extraction.

Preparation of alkaline picrate solution. Twenty five grammes of anhydrous sodium carbonate and $5.0 \mathrm{~g}$ of anhydrous picric acid were added to a 1-liter volumetric flask. The mixture was dissolved in a minimal amount of warm distilled water and the solution was made up to the mark with cold distilled water.

Quantitative determination of cyanide. About $0.1 \sim$ $0.5 \mathrm{ml}$ of cassava or cassava product extract was incubated with $1.0 \mathrm{ml}$ of linamarase preparation containing $30 \sim 40$ units of activity for $10 \mathrm{~min}$ at room temperature in a tall stoppered test tube. The volume of the incubation mixture was made up to $2 \mathrm{ml}$ with $0.2 \mathrm{M} \mathrm{Na}$ phosphate buffer of $\mathrm{pH} 6.8$. At the end of the incubation period, $5 \mathrm{ml}$ of alkaline picrate were added and the resulting solution was incubated in a water bath at $95^{\circ} \mathrm{C}$ for $5 \mathrm{~min}$. Upon cooling to room temperature, the absorbance of the deep orange colour formed was read in a Beckman Model 25 Spectrophotometer as described before. The cyanide concentration was extrapolated from a standard curve (see Fig. 4) previously prepared with potassium cyanide as standard.

\section{RESULTS}

\section{Hydrolysis of cyanogenic glucosides}

The cyanide in cassava and its products occurs in two forms (Fig. 1): (a) the aliphatic cyanogenic glucosides, linamarin and lotaustralin often referred to as bound cyanide and (b) the free nonglycosidic cyanide, $\mathrm{HCN}$. Figure 1 shows the enzymatic hydrolysis of linamarin and lotaustralin to release the free cyanide which can be assayed. Most early methods for releasing free assayable cyanide from fresh cassava tubers relied on acid hydrolysis or spontaneous autolysis by the endogenous linamarase. While acid hydrolysis yielded unwanted side products like amides and ammonia, spontaneous autolysis suffered from the tremendous variation in the endogenous enzyme activity resulting from the heterogeneous plant substrate; the accompanying secondary reactions and the accumulation of hydrolysis products. ${ }^{4}$ Besides, with processed cassava products, all of the endogenous enzyme activity would have been destroyed and there is therefore no question of using spontaneous autolysis to release free cyanide. All these problems were obviated in this work by using partially purified exogenous linamarase of known activity to hydrolyze the endogenous cyanogenic glucosides (principally linamarin) both in the fresh tuber and processed products. Figure 2 shows what could happen if an insufficient amount of enzyme activity is used in the hydrolysis reaction. Using enough of an active linamarase preparation produced the results depicted in Fig. 3.

\section{Colorimetric determination of cyanide}

The absorbance of the characteristic deep orange colour produced upon incubation of
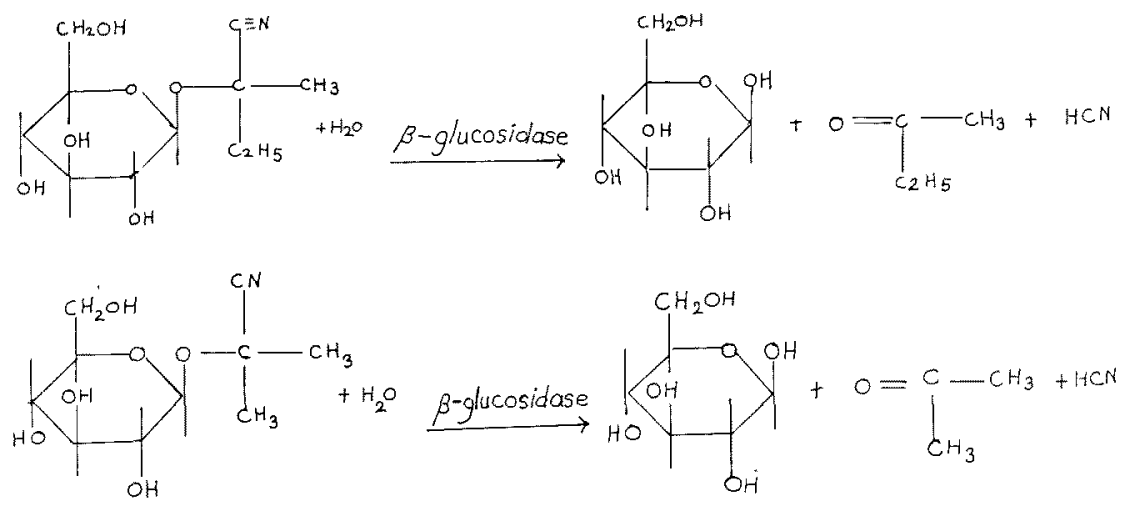

Fig. 1. The Enzymatic Degradation of Linamarin and Lotaustralin. 


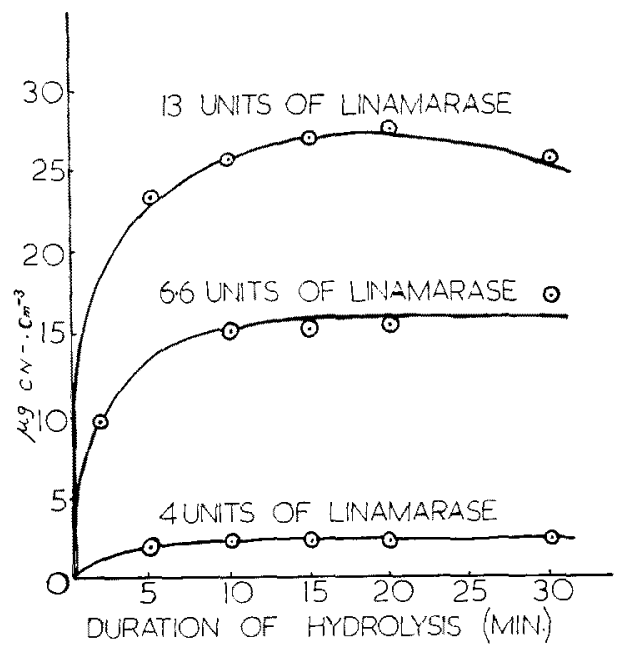

FIG. 2. Incomplete Enzymatic Hydrolysis of the Endogenous Cyanogens in a Diluted Extract of Fresh Cassava Parenchyma Tissue Using Known but Different Linamarase Activities.

The hydrolysis incubation mixture in each case consisted of $0.1 \mathrm{ml}$ of the diluted cassava extract and an amount of partially purified linamarase equivalent to the indicated activity. Cyanide estimation was performed as described in the text.

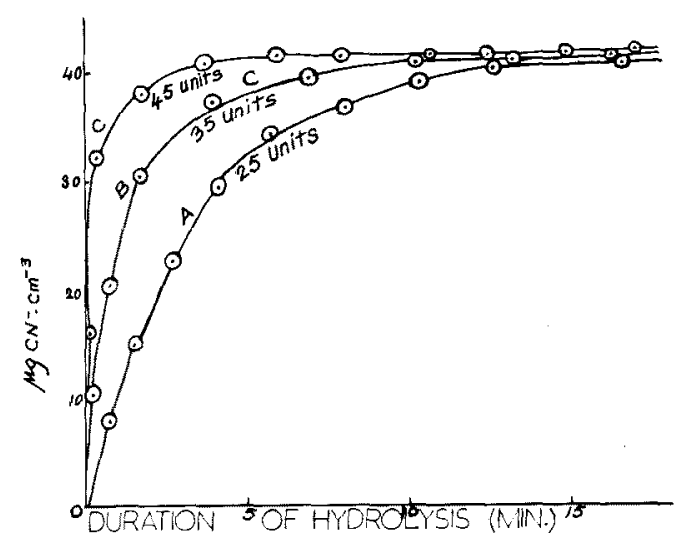

Fio. 3. Complete Enzymatic Hydrolysis of the Endogenous Cyanogens in a Diluted Extract of Fresh Cassava Parenchyma Tissue Using Known but Different Levels of Linamarase Activity.

Incubation and assay were as described in Fig. 3. The following linamarase activities were used in the hydrolysis reaction: A 25 units; B 35 units; C 45 units.

the released cyanide with alkaline picrate, was read at $490 \mathrm{~nm}$. The cyanide concentration was then extrapolated from a standard curve

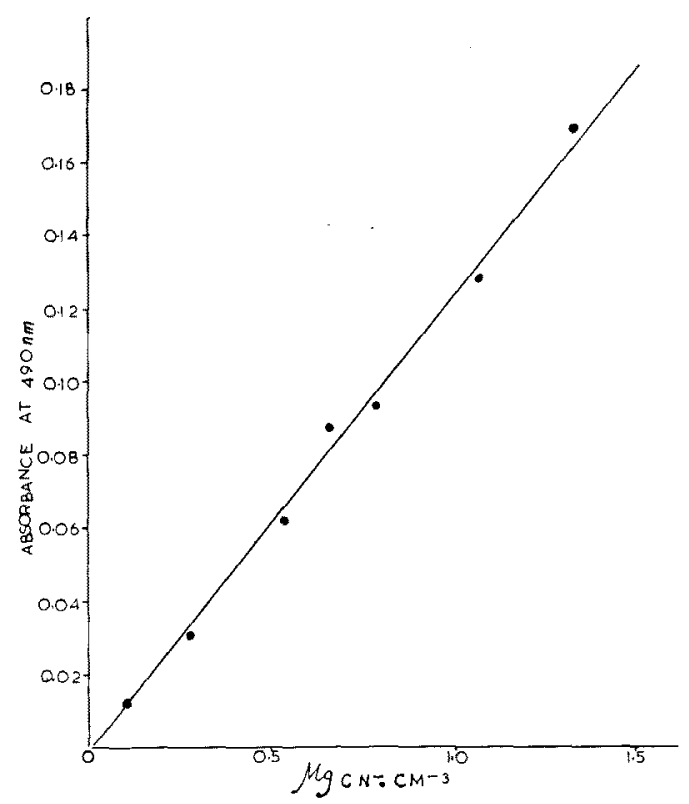

FIG. 4. Standard Curve for Cyanide Estimation.

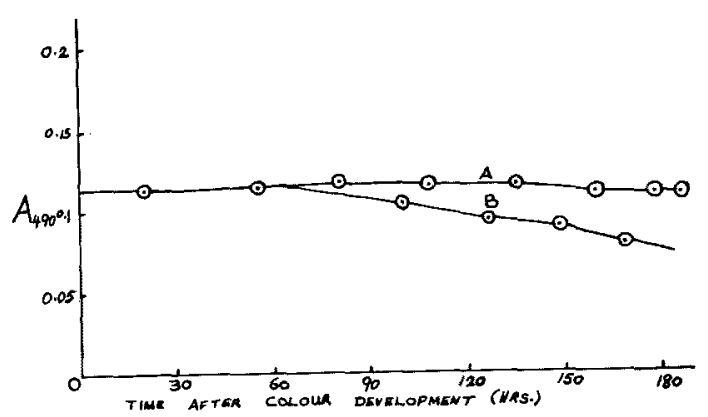

Fig. 5. Effect of Room Temperature and Refrigerated Storage on the $A_{400}$ of the Deep Orange Colour Developed for Cyanide Assay.

A : refrigerated storage, $B$ : room temperature storage.

(Fig. 4) prepared with $\mathrm{KCN}$ as standard. Absorbance readings accumulated for a period of two weeks showed that the chromogenic complex responsible for the orange colour was reasonably stable. Our experiences indicate that the $A_{490}$ of this coloured solution can be read with no real loss of accuracy after one week of refrigerated storage. This is illustrated in Fig. 5.

Possible interferences with the cyanide assay

It has been suggested in the literature ${ }^{5,171}$ 
that picrate may react with aldehydes and ketones to interfere with the quantitativeness of this assay. The most important aldehyde and ketone likely to pose problems in this assay are glucose (i.e. open-chain form) and acetone. Linamarin constitutes $90 \sim 97 \%$ of all bound cyanide in cassava tubers. Substituting glucose at various concentrations for cyanide in the assay protocol did not produce the characteristic colour change indicating infact that glucose does not react with picrate. This is not surprising since the open-chain form of glucose present in solution is extremely insignificant. Acetone on the other hand, did show a positive but very weak colour test with alkaline picrate thus confirming literature speculations. However, subsequent studies involving the use of several known equimolar concentrations of acetone and potassium cyanide and the appropriate controls were conducted to determine the extent of acetone contribution to the observed colour intensity as given by $A_{490}$. Calculations from the data obtained showed that this contribution amounted to only $1.5 \pm 0.02 \%$ which was within the range of the precision of this assay method (vide infra) and so could not be considered significant. Assay trials using a number of reducing agents (e.g., ascorbate, mannose, catechol, succinate, lactate, etc.) likely to occur in fresh or processed cassava parenchymatous tissue, produced negative results.

\section{Sensitivity and precision of the assay method}

Results of sensitivity tests using progressively decreasing concentrations of $\mathrm{KCN}$ as source of cyanide, indicated that the modified alkaline picrate method being reported here was capable of detecting cyanide down to a concentration of $0.16 \mu \mathrm{g} / \mathrm{cm}^{3}$. In other words, the detection limit for this method is $0.16 \mu \mathrm{g} / \mathrm{cm}^{3}$. This compares favourably with Cooke's method which has a detection limit of $0.01 \sim 1.0 \mu \mathrm{g} /$ $\mathrm{cm}^{3}$ ? $^{7}$

Precision is generally evaluated in a number of ways as repeatability, as reproducibility, in comparison of one method with another, and as a comparison of the performance of a number of laboratories analyzing a single nationally distributed sample. Perhaps, the single most important statistical measure of precision is the coefficient of variation (C.V.). The coefficient of variation, given as $\% \mathrm{C} . \mathrm{V} .=$ (S.D. $/$ mean) $\times 100$ where S.D. is the calculated standard deviation of the measurements. For this assay, we obtained a C.V. of $3 \%$ which compares with values considered as acceptable in most clinical analyses. ${ }^{18 \text { ) }}$

\section{Cyanide content of cassava and its products}

Gari, a variant of the South American farinha de mandioca, is by far the most popular form in which cassava is consumed in West Africa. For its preparation, peeled cassava tuber is grated, fermented for $3 \sim 4$ days, then dewatered and finally fried to a moisture content of about $9 \sim 12 \%$. In view of the tremendous importance of this food product in the West African trade and diet, samples of gari from several cassava processing and marketing sources were subjected to analysis for cyanide. Table 1 shows the results obtained from such analysis. Table II shows the cyanide content of other cassava products used for human or animal consumption. Comparison of the cyanide values with that obtained for the fresh

Table II. Cyanide Content of Some Cassava Products ${ }^{a}$

\begin{tabular}{llcc}
\hline & \multicolumn{1}{c}{ Product } & Use $\begin{array}{c}\text { cyanide } \\
\text { content (ppm) }\end{array}$ \\
\hline 1 & Tapioca & Human food & 125 \\
2 & Cassava chips & - & 74 \\
3 & Vita Fufu & - & 132 \\
4 & Cassava flour & - & 81 \\
5 & Vera (floury) & - & 63 \\
6 & Cassava grits & Animal feed & 109.7 \\
7 & Sun-dried cassava chunks & - & 264 \\
8 & Unpeeled, grated and & & \\
& fermented (4-days) cassava & - & 144 \\
\hline
\end{tabular}

a The eight dry cassava products shown above have been produced over the years from bitter varieties of cassava at the Institute's Food Development Laboratory by different methods to yield different product forms. Their moisture content ranged from $9 \sim 13 \%$, although they had been packaged in polythene bags. Cyanide concentration, as explained in Table I, was expressed in ppm. 
tuber indicates considerable detoxification during processing.

\section{DISCUSSION}

The partially purified linamarase obtained by acetone precipitation was 4-fold more active than a crude extract of the enzyme. Contrary to the generally accepted practice in enzymology, it was not necessary to isolate linamarase in the cold room provided extracts containing the enzyme were always placed in prechilled containers or in an ice bath throughout the duration of the isolation. Even refrigerator temperatures $\left(7 \sim 10^{\circ} \mathrm{C}\right)$ were adequate for long term storage of the enzyme. Like polyphenol oxidase from yam tubers, (Diosscorea spp.) the enzyme appears to have acquired evolutionary capacity to withstand tropical temperatures without serious loss of activity. It is therefore possible for laboratories not aquipped with a cold room to isolate this enzyme for routine use in cyanide estimation. Because of the inevitability of extracting some linamarin along with the enzyme, it was necessary to dialyse the final enzyme preparation before using it in cyanide analysis. Due to the unavailability of pure linamarin, the activity of the partially purified linamarase was assayed using an artificial substrate, $p$-nitrophenyl- $\beta$-D-glucoside. Cooke et $a l^{.}{ }^{3}$ have reported a $K m$ of $1.45 \mathrm{mM}$ and $0.46 \mathrm{mM}$ for linamarin and PNP-glucoside respectively indicating that the latter is perhaps a more effective substrate for the enzyme than the former.

In preparing extracts from fresh cassava tubers, an acid solution was used in order to inactivate endogenous linamarase and avoid premature hydrolysis of the extracted cyanogens. The use of acid solutions for the extraction of processed cassava products is recommended in view of the possibility of occasionally encountering improperly processed cassava product with some residual linamarase activity.

The altered starch structure during processing tended to encourage extensive gel for- mation during the preparation of extracts from cassava products thus making it difficult for reasonably water-clear extracts to be obtained. It was necessary, in such cases, to filter the extracts through a layer of glass fibre since centrifugation alone was ineffective.

Provided enough enzyme (Fig. 3) was used, hydrolysis of the endogenous cyanogenic glucosides was usually complete in about $15 \mathrm{~min}$ or less. Because of the volatility of the released $\mathrm{HCN}$ (bp $26^{\circ} \mathrm{C}$ at room temperature) the hydrolysis incubation solution was securely sealed to minimise any losses. It was generally preferable to carry out the hydrolysis reaction in tall stoppered tubes instead of the regular test tubes or beakers. For the assay to be valid, all of the cyanogens in the sample being analysed must be hydrolysed by the enzyme. This was usually assured by using a disproportionately high total enzyme activity in relation to cyanogen concentration or preferably by first carrying out a preliminary study of the type reported in Fig. 3 to determine the proper level of enzyme activity to be used. With experience and a little knowledge of the history of a sample, it is possible to make a reasonably accurate estimate of the proper level of enzyme activity required to achieve total hydrolysis.

Results presented in Tables I and II show that substantial amount of cyanide still remain in processed cassava products. The cyanide values obtained for gari samples ranged from $13 \sim 62 \mathrm{ppm}$. The wide variation in the cyanide values arise from (a) nonuniformity of the processing methods, (b) use of different cassava varieties as raw material and (c) differences in the storage age of the product since Wood ${ }^{13}$ ) has shown that cyanide content of gari declines with the age of the gari in storage. Unfortunately published data on cyanide content of gari and other cassava-based foods are scanty. $\mathrm{Oke}^{19)}$ analysed a sample of market gari and obtained a value of $19 \mathrm{ppm}$ of cyanide while Wood $^{13 /}$ reported a value of $25 \mathrm{ppm}$. There is as yet no general consensus on what constitutes a toxic level of cyanide intake as a result of the tremendous ability of the liver to detoxify much of ingested cyanide. ${ }^{19)}$ However, based 
on the work of Koch, ${ }^{20)}$ Bolhuis $^{12)}$ and deBruijn, ${ }^{21)}$ Coursey ${ }^{22}$ has suggested the following guide to acute toxicity of cyanide:

Innocuous: $<50 \mathrm{ppm}$

Moderately toxic: $50 \sim 100 \mathrm{ppm}$

Dangerously toxic: $>100 \mathrm{ppm}$

Monier-Williams (23) recommended a maximum of $20 \mathrm{ppm}$ for foods eaten raw and $50 \mathrm{ppm}$ for foods treated with cyanide insecticides e.g. dried fruits, since the hydrogen cyanide is liberated on cooking. During an extensive investigation carried out in Nigeria in connection with the mechanized production of gari, Akinrele et al. ${ }^{24}$ argued that a value of $30 \mathrm{ppm}$ HCN was acceptable in this food product. In Brazil, where cassava flours are extensively used in the baking industry, Paula and Range ${ }^{25)}$ obtained cyanide values ranging from $10 \sim 200 \mathrm{ppm}$ from flours produced with bitter (high cyanide containing) varieties of cassava. Nemoto ${ }^{26)}$ gave a value of $27 \sim 37$ ppm as the normal range and stated that grated manioc flour may contain as much as $125 \mathrm{ppm}$. It thus appears that despite the various detoxification methods employed in cassava processing in different parts of the world, products containing appreciable traces of cyanide are still obtained.

It is encouraging to note that the modified alkaline picrate method reported in this paper was found to be reasonably sensitive, reproducible and quite simple to use even by unskilled technicians. The method was found to be ideally suited for the screening of a large number of samples of cassava tissue and products; it has also been adopted at the NRCRI for the examination of cynogenesis in different cassava cultivars in the field. Repeated experience has convinced us that a trained operator working alone can analyse up to 700 samples a day provided the enzyme and all the other analytical reagents were prepared beforehand.

\section{REFERENCES}

1) O. L. EKPECHI, Brit. J. Nutr., 21, 537 (1967).

2) F. Delauge, P. Bourdoux, M. Camus, M. Gerard,
M. Mafuta, A. Hanson and A. M. Ermans, "Proc. IVth Intern. Sympos. on Tropical Root Crops", ed. by J. Cock, R. MacIntyre and M. Graham, CIAT Colombia, 1976, pp. 237 242.

3) B. O. Osuntokum, "Chronic Cassava Toxicity: An Interdisciplinary Workshop", ed. by B. Nestel and R. MacIntyre, London, England, 1973, pp. $127 \sim 138$.

4) A. Zitnak, "Chronic cassava Toxicity: An Interdisciplinary Workshop", ed. by B. Nestel and R. MacIntyre, London, England, 1973, pp.89 96.

5) F. Nartey, Manihot Esculenta (Cassava), "Cyanogenesis, Ultrastructure and Seed germination", Munksgaard Press, Copenhagen, Denmark, 1978, pp. $75 \sim 76$.

6) R. D. Cooke, G. G. Blake and J. M. Battershill, Phytochem., 17, 381 (1978).

7) R. D. Cooke, J. Sci. Food Agr., 29, 345 (1978).

8) R. D. Cooke, Exptl. Agric., 14, 1 (1978).

9) S. Israel, Biochemistry Laboratory, International Institute of Tropical Agriculture, Ibadan, Nigeria, personal communication (1979).

10) M. L. Guiguard, Compt. Rend. Paris, 142, 545 (1906).

11) M. Mirande, C. R. Hebd. Seances, Acad. Sci., 149, 140 (1909).

12) G. G. Bolhuis, Netherlands J. Agric. Sci., 2, 175 (1954).

13) T. Wood, J. Sci. Food Agr., 16, 300 (1965).

14) T. Wood, ibid., 17, 85 (1966).

15) P. Indira and J. K. Sinha, Indian J. Agr. Sci, 39, 1021 (1969).

16) D. G. Gilchrest, W.E. Lueschen and C. N. Hittle, Crop. Sci., 7, 267 (1967).

17) S. J. Van der Walt, Onderstepoort J. Vet. Sci. Anim. Ind., 19, 79 (1944).

18) D. R. Martin and T. C. Hartney, J. Chem. Ed., 55, 239 (1978).

19) O. L. Oke, World Review Nutr. Diet., 9, 227 (1968).

20) L. Koch, "Cassavaselectie," Veenman and Zonen, Wagenigen, 1933.

21) G. H. de. Bruijn, "Etude du caractere cyano" genetique du manioc (Manihot esculenta Crantz) Meded", Landbouwheogeschool, Wagenigen, 71-13: $1 \sim 140$ (1971).

22) D. G. Coursey, "Chronic cassava Toxicity: An Interdisciplinary Workshop", ed. by B. Nestel and R. MacIntyre, London, England, 1973, p. 29.

23) A. Monier-Williams, Analyst, 56, 47 (1931).

24) I. A. Akinrele, A. S. Cook and R. A. Holgate, "Proc. 1st Intl. Congress Food Technol", London, England, pp. $633 \sim 644$.

25) R. D. de. G. Paula and J. Rangel, Rev. Alimentar. (Rio de Janeiro), 3 (29), 215 (1939).

26) Y. Nemoto, Rev. Aliment. Chim. Indust, 4 (33), 5 (1940). 